\title{
The Book That Ate Me
}

\author{
Dore Michelut
}

\section{Le livre qui m'a mangée}

La revanche du récit. L'histoire du processus de production d'Ouroboros; l'histoire de la construction d'un sujet hétérogène dans un mouvement entre quatre niveaux de la conscience, entre quatre modes d'écriture: le poème, le journal, le rêve, le dialogue; le récit d'une transformation de l'écrivaine qui laisse sa peau dans le processus d'écriture pour en sortir avec le corps changé. Ce texte raconte la poursuite obsessive d'un fragment qui refuse l'ordre voulu par la poète et reduit tout en fragments avant de trouver sa place dans une forme composée de relations, dans l'entre-deux. La quête impossible d'une écrivaine pour se voir réelle dans la représentation.

It all started with a seemingly innocuous four-line fragment that insisted on belonging to what was then titled The Crowd Ceases, a collection of my poetry that didn't want it. It was January 1989. After an emotionally exhausting year of writing renga, thinking renga and struggling to put renga into book form without betraying the experience, I was looking forward to retreating with my poetry to a warm, solitary chamber. Ah, to have the page to myself again, I remember thinking that New Year's Eve. I was envisioning an organic whole, a mosaic of feeling parts made by weaving together poetry and dreams, so as to make visible a balance between two states of consciousness working within metaphor. It was to be a quiet and peaceful coming home to myself. And perhaps it could have been were it not for a fragment, a four line headache that refused to stand alone, be incorporated by another poem, be expanded upon, or be left out.

That fragment caused me to break with the seduction of genre by teaching me that the impulse to categorize was not very different from the impulse to narrate: both easily led to fictitious states. But the main lesson was of another order: once the desire for those states was 
leashed, the book form became a place where a chaos of past selves could undergo the process of taking ' $a$ ' written shape. I stress the a, because I discovered that what I could ask from this kind of writing had boundaries: I could not expect a full-bodied self to emerge from a process that drastically diminished my sensory involvement in order to reflect onto a two-dimensional plane. In hindsight, much is clear, and I am even feeling belated affection for the hard lessons of OUROBOROS.

It started well. Thirty or so poems painstakingly written over the past four years merged with my dreams as if there had been a master plan guiding my response to life during that period. And it was a pleasure rummaging through stacks of recorded dreams choosing those that related to the poetry. A month of pleasant, at times delightful work, and it was done. The collection was symmetrical and well wrought: the first part of the book was poetry, the second, dream. Both sections rendered two complementary conscious states at work: one in wakefulness, one in sleep. By juxtaposing the two, I felt some conclusions could be drawn regarding the blanket term, metaphor. So I chucked the fragment back into the fragment pile, and the collection was neat and clean and finished. For almost a whole day. Then, the discarded fragment started nagging me. Rejected, it mocked the book and its claim to represent me. I say mocked because I felt shame, as if I were telling a lie and were for some reason unwilling to rationalize. I finally gave in at 3 o' clock in the morning, got up, and started looking for a way to absorb the fragment into the collection. And so started the six-month odyssey.

Re-working the poetry section, Ilooked for other possible arrangements, other organizations of the material which would sustain the juxtaposition of two separate states of consciousness realizing themselves through metaphor. I tried everything. I divided the poems that were dedicated to people and those that addressedideas while I experienced their contexts. Still, the fragment rankled. Then, in an attempt to contextualize it, I created a whole separate chapter for fragments. And so, I set about unravelling the now-superfluous artifice built to prop some fragments and rescued others from the pile to create a fullbodied section. The fragments would remain what they originally were: unfinished moments in animated suspension replaying indefinitely to a background of contingencies which were no longer in my present. The collection would be poems, fragments and dreams.

It was already February. I had a deadline to meet. I wanted The 
Crowd Ceases to really cease. Since I had been writing and re-writing these pieces for years, deep down I resented the collection demanding such effort. Surely, I thought, working full-time (my waking hours) and full-steam (I thought of little else), one intense burst of work would end it. About 20 fragments were complete when it struck me that a separate chapter for fragments would upset the initial purpose of the collection: I had wanted to present metaphor at work in two states of consciousness. What did fragments as a separate category have to do with all this? It didn't make sense to separate them from the rest of the poetry. The added section caused the manuscript to sag, to become ample and confused; yet without these particular bits and pieces, I felt strongly that the collection would exist for the sake of a fictive voice rather than my own, and that made me feel as if I were betraying the poems and dreams. Either way, it was a dead end. I was becoming extremely frustrated, and I was right back where I had started: imposing a theoretical dress that was literally, not fitting.

Mid-February. I was not enjoying being alone writing. I missed renga, the living 'other' in which to experience myself taking shape. I felt strongly that I was wasting time, and was tempted to just collect the poems and be done with it. But at this point, I could not leave out the dreams. And I was still determined to wrench a structure from the material. So I shuffled and re-shuffled, combined, recombined, scribbled, entered and saved. I used all the editing functions on the computer and worked with five open screens until all the ordering, organizing principles vanished and I was mixing the pieces like a deck of cards searching for the best arrangement: poem to fragment to dream. So be it; an entire book of fragments, then.

Ruthlessly, I edited the pieces to fit each other. To my surprise, I started enjoying it. I was actually writing again, creating new relations where previously there were none, filling in for the selves that had vanished between one piece and another. And it was good. Animated, I drew out the proximity of one piece to another until they fused. Yet despite the familiar elation of a work in progress, the more I worked, the more I despaired. I saw no inkling of my original design and purpose emerge, no external cohesion that I could recognize as form. And I did not trust it. It was already March. I became convinced that I was wasting time yet again. So baffled and resentful did I become, that one day I stared at length at the delete key, and then, simply, I pushed it.

Panic is a strange emotion, perhaps it's differentiated from fear 
because fear paralyses while panic energizes: whatever, it caused me to call all the computer buffs I knew and a few I didn't. It caused me to stay up all night deciphering the directions to a file recovery program. And, it caused me, exhausted and exasperated, at 7 o'clock in the morning to stare at the delete key and push it yet again. This time, I had obliterated the disk directory, and all that my friendly computer buff friends could offer was sympathy. So I went to sleep.

When, the next day, I looked at the entrails of the disk I saw scattered lines arranged by an alien memory whose structuring principle distributed my work into 1,440 sectors organized according to god knows what patterns. I had deleted them. The work was beyond structurelessness, it was random, incomprehensible. With mounting horror, it dawned on me that had I waited, form would eventually have emerged by itself as the result of the process of responding to a felt inner coherence. I could not be both outside, pinning down the form, and inside, developing it. The two actions, reading and writing, opposites as in an equation, could not occur simultaneously or they would cancel each other out. Seemingly simple, yet it had caused me to push that delete key.

Now I could give whatever time and energy the writing process required to fulfil the writing task: whatever was produced, I would accept as my own form. I was inspired again. Wonderful. So I wanted my text back. The floors were strewn with paper debris, but since I hadn't printed out consistently, only the original material was intact. I couldn't believe it. All those beautiful encounters between self and self, those found relations, those synapses had truly disappeared. I just could not believe it. It felt as if a solid object, for me, as solid as the chair I sat on, had literally disappeared into thin air.

Mid-March. It was cold. I missed the unfinished work, mourned it, became resigned and dispirited. Mostly, I hated my computer.

I had to have it back. I couldn't get it back. Between those two statements, another two weeks went by. Salvaging what I could, I rifled through the damaged disk. The rediscovery of a few lines would trigger the memory of a concept and I'd try to re-create the missing piece by relocating the words in memory. Sometimes, having reconstructed them, I would stumble upon the original. Comparing the two, it was clear that although the remembered words contained the concepts, they lacked the cohesion and the urgency of the original insight: I had been trying to re-experience an event by focusing on its product. And I 
never did. I always slid off the point just as I was about to gain it. As if the product of the self shut me out from that same selfhood. Besides, it was bad writing.

And so the revelation: it was impossible to regenerate the specific words from a specific experience simply because I could not (re)occupy what was (pre)occupied by myself; or, I could not be in the same place in two different times. (So much for Borges' 'Pierre Menard, Author of the Quixote'). Writing was not about the object on the page, it was about what I experienced searching for myself on the page; in the end, the capacity for that experience would be the result, not the book object.

If experience was indelible, and not its product, it followed that it would be possible to build on experience as if it were concrete and present. To do this, instead of trying to recapture the specific words, I relocated the feeling the words had generated and proceeded to write as if adding to it. Now I was getting somewhere, although it was disconcerting to treat writing that was not physically present as if it were. An analogy perhaps would serve to clarify: it was like constructing tangible, wooden arm rests on an invisible chair which held firmly as I actually nailed and glued and varnished. In effect, this manuscript was not concerned with defining metaphor, it was making me aware of how metaphor bound and propelled me through matter.

The written poems and dreams were solid, material objects that I claimed represented me, myself. Yet between the writing me and the written objects there was elapsed time which could not be thought chronologically, either hypothetically or de facto, for that time came into being when I recognized relation, and that relation was exposed by metaphor. Moreover, the synapses that established the relationship of the many pieces each to each had to occur within a singular identification between myself and the many that progressively developed as I struggled to hold them all contemporaneously in my mind. Having disbarred narrative, I could allow no inner voices to orchestrate a singular resolution - I could choose movement only from and to what I had already written. $\mathrm{My}^{\prime} \mathrm{I}^{\prime}$, therefore, became a capacity to relate the existing selves rather than a stage that caused the self to multiply for the sake of performance.

Valery's fragmented Cahiers took on new meaning: the self was an accumulation of pieces that had never co-existed, and writing was an opportunity not to narrate, but to create a context of self in which to let 


\section{$30 \cdot$ Tessera}

those pieces gather and relate. But how on earth was I going to hold, in my attention, without chronology or category, four years of poetry and ten years of dreams? I could not, would not, collect those poems and dreams as if a fictive categorical or narrative structure had determined them. I had. So, who was this I? At one point, I understood my long standing sympathy with Augustine's fury at Virgil for placing the self in a postulated untruth which stood for reality - and which young Augustine took as such. I knew that ficticity was something I didn't want to live with; that had been the message of the unyielding fragment.

Looking for association, I found myself casting about for that which caused relation to occur between the pieces. Poetry and dream did not offer enough leg room, so I added another recorded state of consciousness: dialogue. I limited myself to dialogues remembered in my journals or those retrievable in the same way the absent computer material was retrievable. And then, when talking to a friend on the phone one morning, joking that the manuscript was getting to be a smorgasbord, that only my journal entries were missing, he asked: 'Why not include them?' Why not, indeed. The journal entries for the previous year, 1988, supplied a consecutive, rational self at work trying to make sense of the self who was writing poetry during a period when renga was causing great upheaval in my life. Since I had consistently written this ' $I$ ' as truth, I could trust it not to be fictitious, and it provided an ample written master sequence in which the writing self could sustain and absorb, by association, the non-consecutive ' $I$ 's in states of poem, dialogue and dream.

A choice of journal entries, the dialogues - remembered and written, the stacks of dreams since 1980, and the poems - fragments or not - , started dancing on screens that opened and closed in great confusion. The closer I got to any one piece, the less I saw the contours of the whole. From such close quarters, I was blind to what occurred to the overall form, but I doggedly followed the feeling of myself forming. As I felt the whole tighten about me, what had been, was again, but differently. It was almost impossible to grasp all of it for any length of time without falling into schema. Although I perceived glimpses, I could not sustain the whole. If only I could see everything at once, I thought. And lo, the Idea: I printed everything out, and up on the wall everything went.

From the bedroom, onto and out of the door, through the kitchen, 
past the mirror, right out into the hallway. This helped, even if it was an ongoing struggle to retain the sense of the whole in my mind. While I could retain it, synapses sprouted between the pieces, and I worked feverishly. When I just couldn't, I would pace the length of the wall, back and forth: scissors, paste and masking tape. I lost track of day and night as I laboured to grasp the entire wall and keep it still while I brought 576 past selves together. Blindly, I trusted that everything would eventually make sense.

My past was material, and I had to make room for it in my vanishing present. Indeed, this became my task: to make room for myself in myself, to become more capable. As the parts came together, it was amazing to me that the self that had dreamt a dream of fear could laugh at that same fear in a poem. And it was with great satisfaction that I finally placed the uncompromising fragment in between two pieces that wanted it, so that it had nothing more to say.

The difficulty at this stage was in not conceding to the temptations of a fictive self. It was a constant battle to stay on this side of suspending disbelief, to let my past selves stand in for me as they were, occupying their own time apart from any narrative causation I could impose. At times, it felt like I was desperately using all ten fingers to plug leaks in the conditions I had imposed: how could I curtail a dream that would become an epic; and what about a rational thought that needed ten essay pages to sustain it? Or a dialogue that desired to expand into a script? Only the poems behaved and didn't struggle within their confines.

The problem, I felt, was not to bring past self to present self, but to bring the past object to itself in the present: my presence, upon which I imposed the recurring rhythm of four states of consciousness in sequence. Without this sequence, there would have been no momentum to trigger relation, therefore, no progression parallelling the page number: no book. Thus, at the same time as I inhabited each piece, I searched for its place in the whole: when in the poem, I expected the journal, when in the journal, I anticipated the dialogue, when in the dialogue, I forsaw the dream, etc. Cycling like the alternating seasons, I took the time needed to become the state I knew was becoming: I couldn't find a dream that seemed to fit between a journal entry and a poem? At 2 p.m. I would sleep and dream that dream. Or, at 4 a.m., I would suddenly awaken and remember a dialogue that exactly bridged a sequence. I wanted the different activities of the mind to 
take the time they needed but to recur inevitably, much like sleeping and waking. This fixed cycle supplied the underlying grid which caused movement, and yet contained it. I had written all these pieces in utter belief that I was speaking myself; the result of their marriage would form my written self. The writing ' $I$ ' was the glue: it found expression between the lines, it determined the feasibility of each juncture.

March went by. The wall became omnipresent. Nothing else mattered. It so tightened about me that I would pounce on anything meaningful that could be grist for the mill. Nothing was experienced for its own sake: food, love, conversation, all had a destination outside me. My life was remanded and I was displaced. I became frantic, intense, crabby, anxious. I couldn't listen to anyone without imagining their voices on the wall. Then people, that is my friends who could take the punishment, started speaking beyond me directly to my wall. I started hating that wall.

April: I walked down the basement stairs, turned, and was amazed, because although I had just passed by there was nothing there that marked my passing.

May: I walked to the store nearby, stopped in front of a tree and stayed for an hour staring at the exquisite beauty of the budding branches. When I snapped out of it, I understood that I was suffering from sensory deprivation. I felt my body for the first time in months and realized I had gained a lot of weight.

As the world about me faded I felt myself becoming what I made: literally, the writing on the wall, a silent vision of myself wall-bound, an object animated by my own thought. ' $\mathrm{I}$ ' was cannibalizing myself. But what, exactly, was eating me? Not the eventual reader, since I was the reader of what I claimed was me doing what any good reader would do: absorbing the writing into myself until my presence replaced it. Rather, what I assumed as my skin was eating me. Like Ouroboros, the snake that bites its own tail, I moved in the eternal silence of my own possible sound which I shaped so it could relive me page by page (upon which, this account, admittedly, takes a bit of delicious narrative revenge).

My own silence I could live with, since it is background to the construction of any meaningful self; but the page, the physical material upon which I shaped the silent self into an image, maintained utter silence for the duration, and that was a deprivation difficult to bear. What, then, was really happening to me on the page? 
Because the page is external, even within glimpses of the whole, I could only go sluggishly forward and backward; then, it was difficult to accept that two events could not exist simultaneously although I felt that they would if I let them, for without the page, they would merge in me, also, to hold all those discrete, complete, potentially infinite selves in the awareness of self as book was to be greatly diluted; and, by inscribing a cumulative, silent vision of self on paper, I excluded everything else that a language event could bind, touch, smell, taste and sound. In short, my body.

Why was I accepting such distortion? What was this person, whom I truly called ' $I$ ', gaining by becoming fixed in a two-dimensional realm? On the one hand, I was dependent on the page to establish and contain an external simultaneity of self which remained true to itself; on the other, there was no response from the page in return, no life. There. I've written it, said it. No life.

Despite all the nice things I learned in school about aesthetics, I was relentlessly demanding from the page, nothing less than life itself. How is that possible in these postmodern times? Could my great frustration have been nothing but a contemporary version of 'throwing a chisel at the statue', so to speak? But I feel that my experience can't be written off that simply. I suspect that I struggled with the page to such an extent because I am female: my body has a womb, a certainty that it can generate life. From such total involvement, my body expected birth. I cannot ignore that. But then, if not life, what have I created in terms of my own life?

Re-reading Ouroboros today, I admit, I like the woman who emerges even if she is two-dimensional and already receding. She continues not to betray any part of me, and because of this, I am becoming different in a way that otherwise would not have been possible. Still, she is fiction, for no matter how ample the reflection and how profound, what she means always depends on who is looking. Thus, her material existence in book form remains a great, unspoken absurdity, for I know that I don't necessarily have to be her to be who I am; yet, by the same token, she is a constant I have created, and therefore a desirable, possible self yet to be determined because my physical body can only engage reality by walking into a vision of the self. Thus, she is my past and my future. And Western reality is a written reality.

They say anything can be a mirror. Shamans create mirrors in animals and plants; supposedly, even stones are reflective enough to 